\title{
Afghanistan, Taliban, Why
}

Ho Teck Tuak, PhD.

Keywords: Afghanistan, Taliban, Look Good

In the previous eras, the great conqueror Genghis Khan, which by today's standard is just a terrorist group, attack many countries and one of them is likely the Muslim Ottoman Empire, including the Persians, because the Ottoman and Persians challenge them and refuse to surrender to the invaders.

The invaders who likely know and accepting themselves to be generally and genetically big, fat, ugly, and mannered less have the main aim in their conquests to create another species that is opposite or different from what they are. After every conquest, they likely went about impregnating as many as they can and usually is by force. Therefore, in such organizations, the men likely generally do not respect women in their society because they feel all the women that they have are not their kind but are foreigners. Such offspring likely have looks that are a mixture of Mongolian and others and are strangely much better looking than the original Mongolians. And Genghis Khan must have discovered about this from some of the early encounters in his tribes, and for him to set out to do this for his tribes and is one of the many main aims and his solution to the problem for his urgent conquests.

Today the Taliban and similar others who are likely Muslim and likely may have genes and are likely descendants from the Ottoman Empire, have this unknown urge gene to must indiscriminately kill and chase tribes in Afghanistan who are largely having Mongolian genes out of the country. It is called Revenge.

But the Taliban like the Persians likely prefers to always only enjoy themselves, day and night, will likely be unable to manage a government and run a country. And a minority group is likely with conquering ambitions like the Mongolian, but have the added ability to manage government and country will manage the country. And therefore, equivalent to conquering the Ottoman Empire.

Today the Taliban who likely originates from modern-day Pakistan is likely to also have genes from the Punjabis and may have genes from the Ottoman Empire, and if they do not have such genes are only opportunists, and has just seized a new piece of land and expanded their territory.

And history repeats ....., because of the likely desire to look good. 